\title{
Sharon Mueller-Loewald, Quatre figures féminines apocryphes dans certains Mystères de la Passion en France
}

\section{Maria Colombo Timelli}

\section{(2) OpenEdition Journals}

Édition électronique

URL : https://journals.openedition.org/studifrancesi/37251

DOI : 10.4000/studifrancesi.37251

ISSN : 2427-5856

Éditeur

Rosenberg \& Sellier

\section{Édition imprimée}

Date de publication : 15 décembre 2004

Pagination : 583

ISSN : 0039-2944

\section{Référence électronique}

Maria Colombo Timelli, « Sharon Mueller-Loewald, Quatre figures féminines apocryphes dans certains Mystères de la Passion en France », Studi Francesi [En ligne], 144 (XLVIII | III) | 2004, mis en ligne le 30 novembre 2015, consulté le 08 mai 2021. URL : http://journals.openedition.org/studifrancesi/37251 ; DOI : https://doi.org/10.4000/studifrancesi.37251

Ce document a été généré automatiquement le 8 mai 2021.

\section{cc) $($ ) $\ominus$}

Studi Francesi è distribuita con Licenza Creative Commons Attribuzione - Non commerciale - Non opere derivate 4.0 Internazionale. 


\title{
Sharon Mueller-Loewald, Quatre figures féminines apocryphes dans certains Mystères de la Passion en
} France

\author{
Maria Colombo Timelli
}

\section{RÉFÉRENCE}

SHARON MUELLER-LOEWALD, Quatre figures féminines apocryphes dans certains Mystères de la Passion en France, «Fifteenth-Century Studies», 28, 2002, pp. 173-183.

S. M.-L. étudie les quatre figures féminines apocryphes qui reviennent le plus souvent dans les Mystère de la Passion des XIV ${ }^{\mathrm{e}}-\mathrm{XV}^{\mathrm{e}}$ siècles: la femme du forgeron qui fabrique les clous de la croix, Véronique, la vendeuse de soie, la mère de Judas. Ces quatre personnages ne paraissent qu'une fois dans chaque Passion, dans des scènes destinées à amuser ou à instruire le public. Par l'analyse de leur 'milieu', de leur langage, du rapport qu'elles entretiennent avec l'argent, et de leur rencontre avec le Christ, S. M.-L. montre que ces femmes sont en même temps fixées dans leur légende et solidement ancrées dans les mœurs et la vie de leur propre temps. 